\title{
Zllad $\mathfrak{t} \mathfrak{x} \mathfrak{a g}$
}

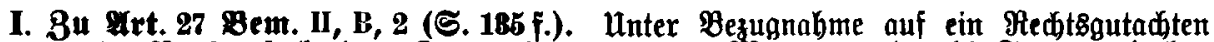

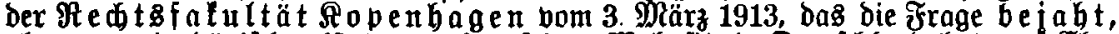

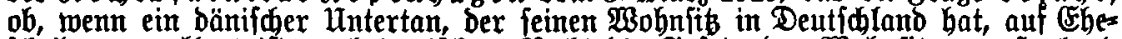

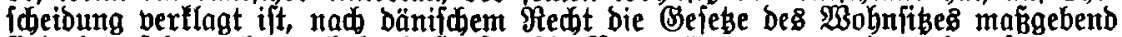
find, Das fobann herborhebt, Daß , für bie Bermögengauseinanderfebung

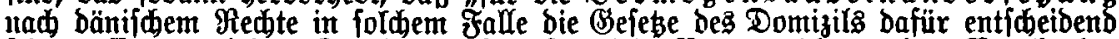
fein müffen, weldes $\mathcal{L}$ andeggefeb für bie Beurteilung bes Berbält= niffeg zugrunbe zu legen ift", ift bem Berfaffer bie frage vorgelegt worben, ob nidt mit?

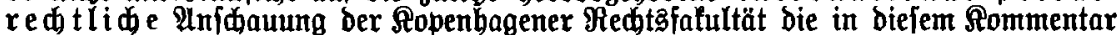

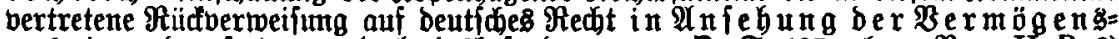
a t se in a nberfebung (bgl. ingbefonbere a. a. D. S. 135 oben, Bem. II, B, 2)

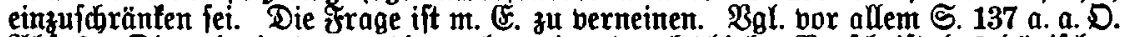

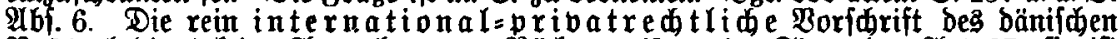

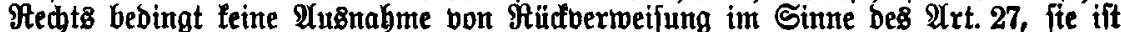

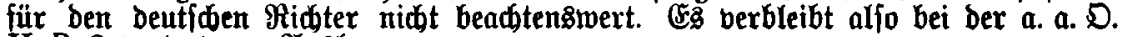
II, $B, 2$, bertretenen $\mathfrak{A} \mathfrak{u}^{3}$ legung.

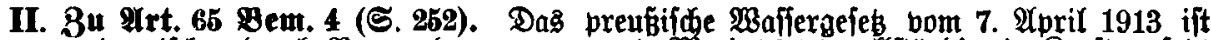

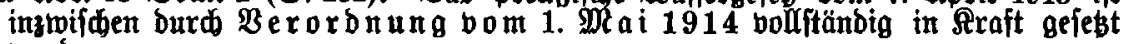
wordent.

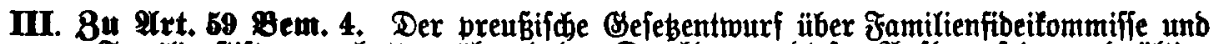
Familien[tiftungen batte toübrend bex Drudflegung biefer Quflage feine enbgültige

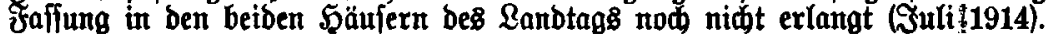

